\title{
10. The Diasporic Canon of Russian Poetry: The Case of the Paris Note
}

\author{
Maria Rubins
}

\section{Reclaiming Diasporic Voices: Unity or Difference?}

The canonical shifts that defined Russian literary history in the late twentieth century entailed not only a massive reassessment of Sovietera verse and the reintegration into the canon of previously silenced voices and texts, but also the recovery of diaspora poets. The rhetoric of a unified literature and canon that emerged in Russian criticism then and which prevails to this day constructs émigrés as prodigal sons, finally readmitted into the fold of national culture. Typical titles of émigré anthologies and prefaces to émigré works published since the glasnost' period recycle a familiar repertoire, spelling out the myth of return: 'Returning to Russia in Verse', 'Homecoming', etc. This celebration of unity was understandable after many decades of division and isolation. The dialogue that was re-launched between the metropolitan and diasporic branches of Russian culture focused on shared elements and common origins in the pre-revolutionary tradition. This perspective was facilitated by the publishing dynamic itself: among the émigré poets first to be printed after the relaxation of censorship were such key figures of the Silver Age as Marina Tsvetaeva, Zinaida Gippius, Dmitrii Merezhkovskii, Georgii Ivanov, Irina Odoevtseva, Vladislav Khodasevich, Konstantin Bal'mont, and Igor' Severianin, whose preexile works were for the most part 'sanctioned' during the Soviet period, 
even if available in limited quantities. In addition to introducing broad reading audiences to their more mature émigré verse, this dissemination offered Russians an opportunity to reconnect to the Silver Age in a new way and to establish continuity between pre- and post-Soviet culture.

However, when the time came to reclaim the second generation of émigré poets, who left Russia at a young age and began their literary careers already in the West, this approach became a handicap: rather than seeking nuance, it glossed over the 'foreign' and 'strange' elements that fit uncomfortably into the native poetic paradigm. As a result, the diasporic specificity of particular poets whose verse was generated as much by their experience of migration, dislocation, and transcultural flows as by the national cultural tradition, has been de-emphasised.

The idea of a fundamental aesthetic homogeneity and parallel development of metropolitan and émigré branches had already been voiced previously in the diaspora itself, provoking a certain resistance on the part of younger poets who argued that their distinct poetic identity could not be circumscribed by a straightforward affiliation with Russian literature. Originally articulated in Gleb Struve's book Russian Literature in Exile (1956), the idea of a unified Russian literature was reinforced at the 1972 Geneva conference 'One or Two Russian Literatures?'. ${ }^{1}$ As Efim Etkind stated at that forum, the separation of Russian poetry into Soviet and foreign was artificial, caused entirely by politics, and bound to give rise to a convergence of both in one literary mainstream once ideological barriers were removed. Moreover, Etkind insisted that 'poetry within and outside the country developed according to the same or similar laws, solving common aesthetic tasks' ${ }^{2}$ Characteristically, to illustrate his position Etkind drew on a limited number of examples, such as the alleged coherence between Tsvetaeva, Pasternak and Maiakovskii, or between pamphlet poems by Gippius and Dem'ian Bednyi. In passing he commented on the differentiation of the younger generation ('poets of the second émigré generation deviated, it seems, from the common path of Russian literature ${ }^{3}$ ) but did not elaborate. Etkind's declaration of

1 In the diaspora this position challenged Soviet ideological discourse, which excluded émigré voices from the Russian canon.

2 Efim Etkind, 'Russkaia poeziia XX veka kak edinyi protsess', in Odna ili dve russkikh literatury?, edited by Georges Nivat (Lausanne: L'Age d'Homme, 1981), pp. 9-30 (p. 16).

$3 \quad$ Ibid., p. 29. 
aesthetic unity across borders was countered by Zinaida Shakhovskaia, on behalf of the younger interwar generation. She insisted on the sui generis character of their literary production, quite different, in her view, from developments in metropolitan Russia. ${ }^{4}$

Such contrasting estimations of the role of the native tradition for émigrés, driven by the empirical material at hand, is another confirmation that émigré literature was far from monolithic and consisted of diverse streams. The optic that highlights the parallelism of twentieth-century Russian poetry inside and outside Soviet borders on the basis of their common origins in the classical tradition is perhaps valid for a number of poetic phenomena of Russia Abroad. It is particularly appropriate for many of the senior poets of the First Wave whose artistic beginnings stemmed from the Silver Age and who continued to cultivate national literary identities in exile. ${ }^{5}$ Geographical displacement of course introduced certain changes into their art, such as new themes, settings or nostalgic retrospection, but these modifications remained rather superficial and inconsequential for their deeper poetic matrix. The older generation of Russian émigré writers, especially those grouped around the Merezhkovskii-Gippius literary salon, regarded themselves as guardians of pre-revolutionary Russian culture. Consequently, rather than exploring new aesthetic dimensions and engaging with opportunities offered by their new locale and with contemporary European art, they often limited themselves to the reproduction of familiar models drawn from the classical Russian canon. But at the same time, in Russia Abroad, there emerged voices that transcended the national framework and produced poetry generated by the very experience of life in the diaspora with its inevitable interstitiality, transcultural diversity and plurality of aesthetic and linguistic idioms. Therefore, discussing such works exclusively from the perspective of the Russian national canon appears problematic.

National canons, at least as they took shape in Western European literatures in the early nineteenth century, articulate certain aesthetic

4 Zinaida Shakhovskaia, 'Literaturnye pokoleniia', in Odna ili dve russkikh literatury?, pp. 52-62.

5 On the contribution of émigré writers to the construction of Russian national identity, see Greta Slobin, Russians Abroad: Literary and Cultural Politics of Diaspora (1919-1939) (Boston: Academic Studies Press, 2013). 
and cultural values, provide an authoritative (albeit constantly revised) set of key models, and thereby promote a vision of a distinct national literary tradition that reflects (and perhaps also informs) a specific version of national identity. This approach fails to account for a large and ever-growing corpus of diasporic narratives that engage with crosscultural sensibilities and practices and articulate emerging, fluid, often conflicted, hybrid and hyphenated identities. Explaining why diasporic discourse has become an object of intense study only now, Igor Maver writes:

Diasporic subjectivities have always coexisted within and outside the long migrant history of a nation but their experience as a text had long been disregarded. However, diasporic (trans)cultural experiences and practices have become today a mode of everyday existence $[\ldots]^{6}$

Due to specific historical circumstances, as a result of almost a hundred years of dispersion Russia has also acquired a global cultural diaspora. Its literary legacy has gradually reached critical mass, calling attention to the emergence of the diasporic canon of Russian literature. Although a great many studies have been written on individual authors and various aspects of émigré writing, the Russian diasporic canon as such has not yet found sufficient conceptual articulation. In what follows, I will present preliminary considerations regarding the taxonomy of the Russian diasporic production, and then develop some of the relevant criteria, focusing on the interwar poetic group known as the Paris Note.

\section{Plurality of Canons and Russian Diasporic Experience}

Although the examination of the distinct character of Russian diasporic culture is long overdue, the plurality of canons more generally has been a conspicuous topic in Western critical writing since the late twentieth century. Many newly-formed canon varieties have been articulated, including postcolonial, transnational, feminist, and Afro-American. These new discourses contest the conception of a unified national canon, dismissing it as elitist and totalitarian, as the heated debates

6 Igor Maver, 'Introduction: Positioning Diasporic Literary Cultures', in Diasporic Subjectivity and Cultural Brokering in Contemporary Post-colonial Literatures, edited by Igor Maver (Lanham and Plymouth: Lexington Books, 2009), pp. ix-xiv, xi. 
around Harold Bloom's The Western Canon: The Books and School of the Ages have demonstrated. At the same time, the canon is reconfigured as a repository of specific values, ideologies, and sensibilities germane to a particular group or a subculture.

The emergence of multiple canonical paradigms is perhaps a natural consequence of mobility, the increasingly porous nature of various geographical, social and cultural boundaries, the empowering of previously marginalised social or ethnic groups, and the resulting fragmentation and hybridization of aesthetic experiences and practices. The mono-national framework is simply no longer sufficient to capture the entire range of cross-cultural and transnational artistic production. And even if, as in contemporary Russia, for example, we witness the opposite tendency to reinforce the nationalist discourse by recycling an old set of aesthetic and ideological symbols, this is most likely just a stubborn reaction against the world's shift beyond the physical and conceptual borders of the nation-state. Rather than simply resisting or embracing this canonical diversity, we should further extend our inquiry, addressing the following questions: what kind of realities and viewpoints do these newly-formed canons represent? What are their fundamental criteria? On what basis are works included or excluded from a canon? And most importantly, how do we expand and deepen the interpretation of a literary text if we approach it from the perspective of a specific canon?

As opposed to newly-articulated canons associated with particular subcultures, diasporic literatures have evolved over thousands of years in extremely diverse contexts, generating an infinite number of diasporic literary models. But contemporary criticism has often framed the discussion of diasporic literary production with the tenets of postcolonial theory, addressed primarily to the work of authors from former colonies who live outside their homeland and write in the language of the former coloniser (such as the Anglophone work of immigrants from India now living in the British Isles, or francophone narratives of North African authors). This postcolonial paradigm does not quite fit the situation of Russian émigrés, despite a number of parallels with postcolonial writers in their way of seeing and representing the world, a nostalgic focus on geographies, the mythic image of the homeland, and the way of inscribing divided or conflicted 
identities. In particular, the difference lies in the fact that most authors of Russia Abroad continued to write in Russian, and the primary point of reference for their narratives is the Russian metropolitan literary tradition rather than that of the host country. Furthermore, the entire colonial context is replaced in Russian émigré imagination by the pain and longing of exile, caused by an oppressive political regime. Indeed, in the Russian experience, the exilic condition has in most cases served as a stepping stone to diasporic identity. Exilic narratives, much like the Ovidian lament, are informed by acute memory of the suffering caused by involuntary departure from home and the desire of return. To use Svetlana Boym's terminology, they are often predicated on 'restorative' nostalgia, on a futile dream of exact reconstitution of the past. Diasporic literature proper, on the other hand, tends to practice a 'reflective' nostalgia that delays homecoming, lingers on the ruins, and engenders an understanding of the irrevocability of the past. ${ }^{7}$ While mindful of the place of origin, a diasporic literary subject mitigates his nostalgia by conceiving of life and belonging as an itinerary rather than as a fixed locus, and creates a complex transitory identity for himself, drawing on his experience of a different place and time to reflect on the present. In other words, diasporic narratives are predicated to a greater extent on the condition of migration, various border-crossings, in-between areas, and transcultural encounters than on the pain of exile and the dream of return.

Diasporic studies see migrancy 'in terms of adaptation and construction - adaptation to changes, dislocations and transformations, and the construction of new forms of knowledge and ways of seeing the world'. ${ }^{8}$ It is worth specifying that 'adaptation' should not be equated with assimilation in a host culture, as in this case one national identity would be simply exchanged for another. Meanwhile, the diasporic 'way of seeing the world' implies not a new, but an extra pair of eyes, a transnational experience of fragmentation, fusion and hybridity. While from the position of a monolithic nation state, diasporic narratives can be read as a subversive counter-discourse, with regard to the Russian artistic experience diasporic and national cultural formations do not establish a

7 See Svetlana Boym, The Future of Nostalgia (New York: Basic Books, 2001).

8 Diasporic Literature and Theory - Where Now? edited by Mark Shackleton (Newcastle upon Tyne: Cambridge Scholars Publishing, 2008), p. ix. 
strict binary opposition. Rather, diasporic and metropolitan culture form a complementary relationship; without negating the national legacy, diaspora offers additional vistas, alternative routes of development and patterns of interpretation, constructing an ambivalent and fluid 'third space $^{\prime 9}$ - a peculiar blend of the memories of the homeland, experience of and reflection on the host culture(s), and imaginary trajectories between the two. Diasporic identities cannot be assigned as stable and fixed entities, rather diasporic belonging is enacted through narrative. When diasporic characters perform themselves through narration, they render national identifications unreliable or irrelevant. This challenge to the protocols of essentialist and homogeneously constructed versions of national identity often takes form not of direct confrontation and negation but as veering off, sidestepping, adding variations to the theme, defamiliarising, or proceeding in a 'knight's move', according to Viktor Shklovskii's famous metaphor.

The origins of contemporary diasporic Russian literary culture can be found in the work of a number of interwar émigrés who gradually turned away from the 'mission' of preserving the national legacy and the teleology of return to exploring the diasporic imaginary, stimulated by mobility, displacement and new cultural experiences. Most of such verbal artists belonged to a younger and more dynamic generation, who refused to live by past alone. Their émigré peers were quick to accuse these younger writers of betraying their origins and writing 'like foreigners' (a frequent charge levelled against Vladimir Nabokov and Gaïto Gazdanov, among others), without delving deeper into the reasons for such a turn. Indeed, there were few attempts at the time to define the distinct character of this new writing, even on the part of the younger émigrés themselves. Deeper reflection came much later,

9 'Third space' has become a trendy concept in interdisciplinary sources on postmodernist cultural production. In Location of Culture (London: Routledge, 1994), Homi Bhabha interprets 'third space' as a creative form of cultural identity produced on the boundaries between forms of difference, in particular in overlaps across the spheres of nation and location. For Edward Soja, third spaces are simultaneously material and mental, or real and imagined, resulting from negotiations between physical realities and mental or cultural constructions. More importantly, third spaces are spaces of transition between localities and over time (Edward Soja, Thirdspace: Journey to Los Angeles and Other Real-and-Imagined Places (Oxford: Blackwell, 1996)). 
as for example in Zinaida Shakhovskaia's articulation of the diasporic specificity of Vladimir Nabokov:

The pinnacle of émigré literature is Vladimir Nabokov, a writer who could not have appeared in the Soviet Union. [...] In the airless space of emigration, Nabokov created an airless and signal literature, a soulless world of symbols, grotesques and parodies - non-beings. He also created his own language, mastering it with years, mixing all languages known to him, transforming geographical names and proper nouns into puns. This restlessness, which he consciously chose after it had been pressed upon him by history, Nabokov brought to perfection and became a free-floating island, separated from the native continent. ${ }^{10}$

Similarly, Vladimir Markov defined the poetics of Georgii Ivanov as informed primarily by the experience of emigration:

Georgii Ivanov is a poet of Russian emigration because in emigration and thanks to it, he became a singular and original poet. It is also important that in his poems he wrote more than others about emigration and from the émigré point of view. Many writers and poets of Russia Abroad tried to blur this point of view and conceived of their often remarkable tableaux of the past as part of the great and majestic preceding tradition. In Georgii Ivanov, this past is an openly nostalgic (or ironic) reminiscence, and it is 'subjectively local', i.e. not only personal 'in general' but also written down by a person located in a particular spot. This endows his verse with distinct concrete lyricism. In this sense, Georgii Ivanov is perhaps the most unquestionable jewel of emigration. ${ }^{11}$

In the same article, Markov comments on Paris Note poetry as constituting merely a 'footnote' to Ivanov's verse. ${ }^{12}$ While this opinion was hardly intended as a compliment to Ivanov's disciples, a reference to them in the same context confirms their affinity with the premier poet of Russia Abroad. Perhaps falling short of Ivanov's artistic excellence, the Paris Note poets responded to the challenges and anxieties inherent in their condition as uprooted migrants, suspended between the distant Russian homeland and the immediate reality of interwar France. And arguably, they did this even more starkly than their maitre, stripping their verse of anything extraneous to crystallise the diasporic condition of deracination and hybridity.

10 Shakhovskaia, p. 61.

11 Vladimir Markov, 'O poezii Georgiia Ivanova', Opyty, 8 (1958), p. 85.

12 Ibid., p. 85. 


\section{The Paris Note: Diasporic Imagination in the Making}

What came to be known as the Paris Note (Parizhskaia Nota) was a loose group that formed around Georgii Adamovich in the 1930s. While there is no definitive list of its members, most critics agree that the ethos and poetics of the Paris Note were expressed most consistently by Anatolii Shteiger and Lydiia Chervinskaia, in addition to Adamovich himself and, as mentioned earlier, Ivanov, who was for them an important inspirational figure. Among other names mentioned in this context are Igor' Chinnov, Raisa Blokh, Irina Knorring, Perikl Stavrov, and, to a limited extent, Boris Bozhnev, Dovid Knut, and Odoevtseva. Meanwhile, the verse of Boris Poplavskii, who may have even coined the group's name, deviated significantly from Paris Note poetics.

The distinct position of Paris Note poets in Russia Abroad has been highlighted in a number of studies on émigré verse. Roger Hagglund even considers the Paris Note 'the very antithesis' of Russian literature of exile. Echoing Claudio Guillén, ${ }^{13}$ Hagglund defines the Paris Note legacy as 'literature of counter-exile' because their verse transcended autobiographical reflection on loss to convey 'a metaphysical concern with the eternal themes of life, the so-called "final questions" of man's origin, destiny, and purpose'. ${ }^{14}$ According to Vadim Krejd, 'The Paris Note is one of the pages of poetry that cannot be overlooked. With regards to émigré literature, the "Note" in it is not a mere page, but a whole chapter, and one of the most conceptual'. ${ }^{15}$ The group's original character was obvious to those who witnessed the evolution of émigré literature at close range. In his 1942 survey of Russian Parisian poetry, Georgii

13 Claudio Guillén proposed to differentiate between 'literature of exile' and 'literature of counter-exile'. The former focuses on 'an autobiographical conveyance of the actual experience of exile itself', whereas the latter refers to writers moving beyond their experience of exile 'toward integration, increasingly broad vistas or universalism'. Triumphing over 'the separation from place, class, languages, or native community', the literature of counter-exile, according to Guillén, offers 'wide dimensions of meaning that transcend the earlier attachment to place of native origin' (Claudio Guillén, 'On the Literature of Exile and Counter-Exile', Books Abroad, 50 (1976), 271-80 (p. 272)). In essence, this opposition captures the distinction that I draw here between exilic and diasporic literature.

14 Roger Hagglund, A Vision of Unity: Adamovich in Exile (Ann Arbor: Ardis, 1985), pp. 38-39.

15 Vadim Krejd, 'Chto takoe "Parizhskaia nota"', Slovo/Word, $43-44$ (2004), http:// magazines.russ.ru/slovo/2004/43/kr41.html 
Fedotov suggested that the original and independent character of the Paris Note stands in sharp relief against the backdrop of epigone verse duplicating Russian (mostly Petersburg) poetics: 'Take away the School [Paris Note - M.R.] and only separate voices will remain, continuing to rehash pre-revolutionary - mostly Petersburg - poetry ${ }^{\prime}{ }^{16}$

This is not to say that the Paris Note members were weakly connected to the Russian tradition. After all, their mentors, Adamovich and Ivanov, themselves represented Petersburg modernism, and they were keen to engage in an intertextual dialogue with the Russian classics and the Silver Age. ${ }^{17}$ However, their main raison d'être was to express a sense of anxiety and alienation in the dehumanised contemporary metropolis, to articulate the perceived entropy of European civilisation, and to leave a testimony of their existence through a creative act. The interwar Parisian chronotope offers crucial context for their verse. Rather than reminisce nostalgically about forsaken Russia as a 'paradise lost', in the vein of some of their older peers, the poets of the Paris Note inscribed their experience of exile into the interwar modernist crisis narrative. They created poetic language adapted to addressing the key concerns of the time, writing in a style reminiscent of the human document, a genre pervasive in the prose and verse of the Western 'lost generation'. In this way, Paris Note members defied the mono-national construction of their poetic identity and transcended the Russian canon without abandoning it. In order to appreciate the hybrid character of their poetry, we need to reconstruct the contemporaneous cultural context, to provide insight into the challenges that these texts sought to address.

16 Georgii Fedotov, 'O parizhskoi poezii', Voprosy poezii, 2 (1990), pp. 231-38 (p. 237).

17 This perspective, framing Paris Note poetry exclusively within the Russian tradition, and in particular as a continuation and 'conclusion' of the Silver Age, has been frequently recycled in Russian critical literature today (e.g. Oleg Korostelev, “"Parizhskaia Nota" russkogo Monparnasa', http://institut-est-ouest.ens-lsh.fr/spip. php?article302 and "Bez krasok i pochti bez slov..." (poeziia Georgiia Adamovicha)', in Georgii Adamovich, Stikhi, proza, perevody (St Petersburg: Aleteia, 1999), pp. 5-74; Kirill Ratnikov, 'Sud'ba "Parizhskoi noty" v poezii russkogo zarubezh'ia', http:// zhurnal.lib.ru/p/petrushkin_a_a/ratnikov.shtml; Ol'ga Kochetkova, 'Ideinoesteticheskie printsipy "parizhskoi noty" i khudozhestvennye poiski Borisa Poplavskogo' (unpublished doctoral thesis, Moscow State University, 2010), http:// www.dissercat.com/content/ideino-esteticheskie-printsipy-parizhskoi-noty-ikhudozhestvennye-poiski-borisa-poplavskogo 


\section{The Crisis of Poetry}

Considered broadly, the literary context of the interwar period was informed by the general existential crisis provoked by World War One (intensified in the Russian émigré case by the trauma of revolution and exile); transformation of the aesthetic paradigm all across European literature; and the increasingly precarious position of the artist in a world of mass culture and mechanical reproduction, which, as Walter Benjamin argued in his seminal essay, threatened to compromise the uniqueness and authenticity of artwork by decoupling the creator and his creation. ${ }^{18}$ One of the corollary effects of these tendencies was a crisis of poetry, actively debated by diaspora poets and critics.

The feeling that poetry was no longer possible was pervasive in the diaspora. This was one of the rare points on which the two leading émigré critics, Adamovich and Khodasevich, who engaged in an energetic polemic on various other subjects, were content to agree. One of Khodasevich's articles bore the straightforward title: 'Krizis poezii' ('The Crisis of Poetry', 1934). As for Adamovich, the crisis of poetry was his recurring topic for years, and he often quoted Valerii Briusov's words, 'Gentlemen, write prose!' ('Пишите прозу, господа!') when discussing in the press the deplorable condition of émigré literature. Writing in the newspaper Mech on April 5, 1936, Alfred Bem stated unambiguously that émigré poetry had reached a dead end. Vladimir Veidle, who in his book Umiranie iskusstva (The Dying of Art, 1937) came to the sad conclusion that Western art and literature in general were not viable, was no less pessimistic when evaluating the condition of émigré poetry: 'Émigré verse is written at a time profoundly unpropitious for poetry ${ }^{\prime 19}$ In practice, this crisis translated into a dramatic decrease in the volume of poetic production and publications, even among the older and well-established poets. Gippius, for example, released only one collection, Siianiia (Radiance, 1938), during the two post-revolutionary decades. After publishing Rozy (Roses, 1931), Georgii Ivanov practically

18 Walter Benjamin, 'The Work of Art in the Age of Mechanical Reproduction', in Illuminations, edited by H. Arendt, translated by H. Zohn (New York: Schocken, 1969), pp. 217-51.

19 Vladimir Weidle, 'Antologiia zarubezhnoi poezii', in Iakor': antologiia russkoi zarubezhnoi poezii, edited by Oleg Korostelev, Luigi Magarotto and Andrei Ustinov (St Petersburg: Alateia, 2005), pp. 218-22, 219. 
stopped writing verse until well into the 1940s. ${ }^{20}$ His nihilist 'Raspad atoma' ('Disintegration of an Atom', 1938), which Ivanov himself preferred to define as a poema (the term usually denotes a long poem with narrative elements), inaugurated a long period of complete silence. Odoevtseva, who during her Petrograd days could not conceive of trading the 'high' status of a poet for prose, switched to the genre of short stories and eventually to the novel from the middle of the 1920s, composing verse only occasionally. Nor were the interwar decades terribly prolific for Viacheslav Ivanov, whose cycle 'Rimskie sonety' ('Roman Sonnets') created in the mid-1920s as a postscriptum to his pre-émigré period, was published eleven years later (in Sovremennye zapiski, 62, 1936). Poetic revival began for Ivanov only in 1944 with 'Rimskii dnevnik' ('Roman Diary'), but by then his distinct manner had undergone a drastic change (its new, diaristic aspect was signalled by the key word in the title). Khodasevich's only new cycle composed in emigration and included in his 1927 Sobranie stikhov (Collection of Poems) was suggestively titled "Evropeiskaia noch" ('The European Night'). Thereafter he wrote mostly criticism and memoirs. According to Iurii Mandel'shtam, Khodasevich was 'broken by the prose of life, the un-transfigured matter'. ${ }^{21}$ Contemplating Khodasevich's poetic silence, Struve comes essentially to the same conclusion:

Khodasevich's path [...] anticipated this end, this hopeless poetic dead end. Perhaps this path [...] is a path of ripening and perfection. But this ripening is linked with the ever increasing realization of a tragic split and just as tragic discord with the world - and no less keen realization of poetry's impotence. [...] our epoch pressed down upon his poetry like some terrible nightmare. ${ }^{22}$

Adamovich also published only one book of poetry after emigration, Na Zapade (In the West, 1939), which comprised some poems from the pre-exile period.

20 Ivanov's book Otplytie na ostrov Tsiteru (Departure for the Island of Cythera) although it came out in 1937, contained for the most part previously published poems, including some from his early, pre-émigré period.

21 Iu. Mandel'shtam, 'Gamburgskii schet: po povodu Antologii zarubezhnoi poezii', in Iakor': antologiia russkoi zarubezhnoi poezii, pp. 230-36 (p. 233).

22 Gleb Struve, Russkaia literatura v izgnanii (Paris: YMCA, 1984), p. 144. See also Tania Galcheva, 'Krizis molchaniia v poezii Vladislava Khodasevicha i v proze Georgiia Ivanova', Slavia Orientalis, 44: 4 (1995), pp. 503-13. 
This obvious decline in poetic potential among the most authoritative members of the Russian diaspora, including those who regarded themselves as mentors of the younger generation (Gippius, Ivanov, Khodasevich, Adamovich), hardly served as an inspiring example. Therefore, the significance of their mentorship for the new voices of the diaspora should not be overestimated. It is quite plausible that the aesthetics of the younger Parisian poets was developing not so much under the tutelage of the iconic figures of the Silver Age as in reaction to their 'death throes'. ${ }^{23}$

More importantly, the crisis was accompanied by general disillusionment with the core values associated with the classical Russian canon. The discourse that promoted the cult of the poet; his sacred, prophetic status; his function as a mediator between the transcendental world and visible reality, and, consequently, the conception of poetry as a mystical, theurgical activity, was rapidly losing its credibility in the eyes of those who had lived through national catastrophe and then witnessed the collapse of European civilisation. From their point of view, Pushkinian aesthetics could no longer offer sustenance in distress and had been revealed to be untrustworthy (this feeling of deception was accentuated in the refrain of Ivanov's 'Raspad atoma': 'Pushkin's Russia, why have you deceived us, Pushkin's Russia, why have you betrayed us?'). ${ }^{24}$

There were certainly more basic causes for the plummeting prestige of poetry and, indeed, intellectual literature, in the diaspora. With the exception of the literary situation in Berlin at the beginning of the 1920s, émigré writers were barred from the Soviet book market. The circle of diaspora readers was progressively shrinking, and their purchasing power was diminishing as well, especially after the outbreak of the global economic crisis. Russian-language periodicals often closed after just a few issues, and only a handful of Russian-language publishing houses were able to endure for more than several years. The general profile of the émigré audience, its level of education and literary tastes also changed considerably. In his article 'Bez chitatelia'

23 Iu. V. Zobnin, Poeziia beloi emigratsii: 'Nezamechennoe pokolenie' (St Petersburg: SPbGUP, 2010), p. 16.

24 Georgii Ivanov, 'The Atom Explodes', translated by Justin Doherty, Slavonica, 8: 1 (2002), 42-67, p. 64. 
('Without a Reader', published in Chisla, 5, 1931), Ivanov lamented the disappearance of the intellectual reader. Gazdanov elaborated on this problem in his controversial article 'O molodoi emigrantskoi literature' ('On young émigré literature', published in Sovremennye zapiski, 60, 1936). He explained that the former intelligentsia - lawyers, doctors, and journalists - had been cut off from the 'cultural stratum' in exile, forced to join the ranks of manual workers and cab drivers. In his article 'Literatura v izgnanii' ('Literature in Exile', published in Vozrozhdenie on 27 January and 4 May, 1933), Khodasevich also focused on limited readership as one of the reasons for the tragic lot of émigré literature. The first draft of this article bore the eloquent title: 'Otchego my pogibaem?' ('Why are we perishing?'). Clearly, this situation was detrimental for poetry to a far greater extent than for prose. While in fin-de-siècle Russia poetry reading might have been a routine activity for the educated general public, it was no longer in high demand in a shrinking and impoverished émigré community with the precarious legal status of apatrides (stateless persons), either unemployed or eking out an existence by hard labour. Those who continued to read during rare moments of leisure required light and entertaining fare, prompting émigré editors to give preference to belletristika (middlebrow, rather than high literature) and mass fiction.

\section{Avant-Garde versus Art Deco}

In addition to the particular Russian historical circumstances, the crisis of émigré poetry can be traced to specific socio-cultural trends on the contemporary European scene. The post-World War One period was characterised by several contrasting (although occasionally overlapping) aesthetic models. At one end of the spectrum there was extreme avantgarde experimentation, provocative liberation of the literary form from any conventional norms, unrestricted self-expression of unique individuality and the subconscious. The other end was distinguished by the efforts to re-create a uniform, universal style, drawing on the new visions of realism and neoclassicism, on the principles of utility, technological progress, and standardisation of living, to re-focus on the physicality of the world and the vitality of the human body. Avant-garde tendencies, expressed most vocally through Dadaism and surrealism, 
clashed with the rising mass culture and the spirit of consumerism, which eventually crystallised in the transnational Art Deco style. Yet, these two seemingly antithetical trends explored a number of similar areas, sharing an interest in urbanism, cinema, and syncopated rhythms, which expressed so well the tremendous acceleration of life during the Jazz Age. Ultimately, these contrasting phenomena jointly contributed to the articulation of a new concept of modernity. This rapidly evolving, eclectic and vibrant modern culture formed the context to which Russian Parisian poets were indirectly responding and against which they should be read and interpreted, in addition to the native poetic legacy.

In the 1920s, many Russian émigrés were toying with avant-garde movements and establishing their own avant-garde groups, such as Gatarapak, Cherez, and Palata Poetov. Poet and painter Serge Sharshun was an active member of Dada and took part in their public performances, masterminded by Tristan Tzara. In his artwork, Sharshun not only synthesised visual and verbal media, but also fused random fragments of Russian and French, thereby increasing its transrational quality (zaum'). In 1921, he published his first Dadaist poem in French, 'Foule immobile' ('The Immobile Crowd'). Later Sharshun joined the poetic association Cherez. Many of his Dada and avant-garde texts in Russian were collected in Nebo kolokol. Poeziia v proze, 1919-1928 (The Sky Bell. Poetry in Prose, 1919-1928, 1938). A genre particularly favoured by Sharshun was the listovka (leaflet). He produced and duplicated leaflets himself and usually hand-delivered them to his bohemian acquaintances. Although some leaflets contained a paragraph or even a page-long text, most commonly Sharshun produced aphoristic, puzzling one-liners, for example: 'Аэроплан - зажег в небе свечку' ('Airplane - lit up a candle in the sky'); 'Небо - полно ангелов' ('Sky - full of angels'); 'Голуби - искупались в радуге' ('Pigeons - took a swim in the rainbow' $)^{25}$

Another poet who was avidly assimilating the style of Dada and surrealism was Poplavskii. His verse is steeped in surrealist imagery, illogical sequences, and hyper-metaphors, which can be illustrated by

25 'Iz listovok S. Sharshuna. Publikatsiia R. Gerra', The New Review, 163 (1986), pp. 127-39 (p. 132). 
such characteristic examples as 'Бледнолицые книги склонялись к железным рукам'26 ('Pale-faced books bent down to iron hands') or:
А ночной король на солнце ходит
С мертвой головой,
Бабочек он тонкой сеткой довит
Голубой. ${ }^{27}$
('Мистическое рондо III').
Meanwhile the King of Night walks on the sun
With a dead head.
He is catching butterflies in a fine net,
A fine, pale blue net.
('Rondo Mystique III' $)^{28}$

The title Avtomaticheskie stikhi (Automatic Verses, 1999), given to Poplavskii's posthumous collection by its late twentieth-century editors, seems to point to the Surrealist écriture automatique created by transcribing random utterances articulated from a trance-like state. ${ }^{29}$ Eventually Poplavskii began to tone down his Surrealist imagery, making it more comprehensible. His brief but intense poetic evolution was punctuated by a steady movement away from avant-garde excesses, even if he never reached the verbal asceticism characteristic of the Paris Note.

One of the factors that contributed to the crisis of poetry in the late 1920s may therefore be excessive avant-garde experimentation that pushed the language to the limits of intelligibility, weakening its communicative function, transforming poetry into a solipsistic

26 Boris Poplavskii, Avtomaticheskie stikhi (Moscow: Soglasie, 1999), p. 65.

27 Idem, Sochineniia (St Petersburg: Letnii sad, 1999), p. 92.

28 Boris Poplavsky, 'Rondo Mystique III', translated by Ron Loewinsohn, in The Bitter Air of Exile: Russian Writers in the West 1922-1972, edited by Simon Karlinsky and Alfred Appel Jr. (Berkeley, Los Angeles and London: University of California Press, 1973), p. 291.

29 However, in Dmitrii Tokarev's opinion, Poplavskii's approach to composition differed significantly from the tenets of the Surrealists, and therefore his affinity to the French movement should not be pushed beyond acknowledgement of a certain similarity of topoi (Dmitrii Tokarev, 'Mezhdu Indiei i Gegelem': Tvorchestvo Borisa Poplavskogo v komparationoi perspektive (Moscow: NLO, 2011), p. 79). 
performance, or a 'corporate' activity addressed to a narrow circle of the initiated. As a result, by and large poetry lost its appeal for 'lay' readers. This tendency was common across the Soviet/diaspora divide, although each side proposed its own way out of the poetic dead-end. Contemplating this problem in the Soviet context, Kevin Platt suggests that the increased complexity of poetry during the avant-garde period led to the collapse of traditional engagement with verse among broad reading audiences, and that the institutionalisation of Socialist realism was a way to save poetry as a mass art. ${ }^{30}$ It would be fair to assume that in the diaspora, instead of Socialist realism, it was the younger poets' verbal practice, with its emphasis on formal poverty, thematic simplicity, and understated lyricism, that represented a potential mechanism for rescuing poetry from the linguistic and semantic violence of the avant-garde. New minimalism called for a return to a new version of classicism, a trend that Iurii Terapiano detects in émigré verse from 1925. ${ }^{31}$ This poetics was crystallised several years later in the output of the Paris Note, which can be regarded as the prime example of the solution provided in emigration to the important aesthetic dilemma of the time.

Another threat to the traditionally 'elevated' status of poetry was presented by the up-beat ethos of the Jazz Age. The rise of mass culture in the 1920s brought to an unprecedented level the artist's dependence on public taste, which was shaped by the culturally programmed desire for entertainment, constant movement, and enjoyment of life through travel, dance, jazz music, film, and sports. New technological achievements put automobiles, transatlantic liners, planes, trains, gramophones, and movie theatres at the disposal of a large number of consumers. Advertisements, radio and movies were actively promoting this dynamic way of life around the globe, advocating universal reconciliation and a carefree, urban and libidinous culture based on a hedonistic mindset. Art Deco art and literature quickly assimilated the spirit of the age, offering a universal vocabulary and a new model for interpreting reality, and creating a corresponding set of aesthetic

30 Kevin Platt, 'O iambakh i posledstviiakh, prichinakh i trokheiakh', Novoe literaturnoe obozrenie, 114 (2012), pp. 264-68.

31 See Iurii Terapiano, Vstrechi (New York: izd-vo Chekhova, 1958), pp. 150-51. 
patterns and themes. ${ }^{32}$ Characterised by fusion and eclecticism, Art Deco transcended all boundaries: between high and low culture; different arts and spheres of human activity; social and ethnic groups; past and present; archaic, classical and avant-garde; tradition and innovation; public and private; monumental and human-scale dimensions. The only context required for the new style was provided by the urban metropolis, which facilitated the removal of barriers between the individual and the city through new principles of architecture and interior design. Behind a highly decorative and carefree veneer, Art Deco, ostensibly devoid of any ideological dimension, hid an aesthetic mechanism for shaping social practices and private routine.

Dislocated by mass culture, literature was rapidly losing its autonomy; the boundaries separating high art from popular entertainment became blurred. Meanwhile, the strong emphasis on the physical body and the environment eclipsed readers' interest in introspection and the exploration of spirituality, which had been a conventional domain of poetry. Intelligentsia of the interwar period questioned the very possibility of creative activity in the post-apocalyptic world of mass consumption and mechanical reproduction that duplicated art, stripping it of its sacred aura.

\section{Poetry versus Cinema: Rivalry and Imitation}

During the Jazz Age, the main challenge to literature came from cinema, perceived as the epitome of modernity, capable of displacing and replacing traditional artistic media. Gradually, the rivalry between literature and cinema evolved into fusion and imitation, as texts began to draw on film-script techniques and to adopt cinematographic poetics. The 'cinematographization' of aesthetic reality affected both the avantgarde and Art Deco in equal measure, conflating their poetic practices and creating overlapping stylistic affiliations for texts that engaged with the seventh art. This modern kind of ekphrasis was exemplified, for instance, by poèmes cinématographiques, composed by Philippe Soupault and other Surrealists. In 'Charlot mystique' (1918), Louis Aragon

32 On Art Deco as a literary style see Michel Collomb, Littérature Art Deco (Paris: Méridiens Klincksieck, 1987) and the chapter 'Challenges of the Jazz Age' in Maria Rubins, Russian Montparnasse: Transnational Writing in Interwar Paris (London: Palgrave Macmillan, 2015), pp. 113-61. 
welcomed Charlie Chaplin as a harbinger of modernity and the silver screen as another channel of communication with mystical surreality.

Such enthusiasm for cinema contrasts markedly with the attitudes cultivated by some of the more conservative poets, who still resisted the pervasive practice of border crossing, either between national canons or between 'high' and 'mass' art. For example, in 'Ballada' ('Ballad', 1925), Khodasevich dismisses Chaplin's performances as sheer 'idiocy':

Мне невозможно быть собой,

Мне хочется сойти с ума,

Когда с беременной женой

Идет безрукий в синема.

Мне лиру ангел подает,

Мне мир прозрачен, как стекло, -

А он сейчас разинет рот

Пред идиотствами Шарло. ${ }^{33}$

I can't be myself,

I feel like going mad

When with his pregnant wife

An armless man goes to the cinema.

An angel hands me a lyre,

The world is clear to me, like glass,-

And he will now open his mouth wide

At the idiocy of Charlot.

Restating the canonical Russian myth of the poet as prophet, the second of the quoted stanzas posits an unbridgeable gap between poetry writing as communing with the angels and the cheap antics of an American comedian, destined for the primitive entertainment of the simple-minded. Yet, at the end of this poem the lyrical persona acknowledges that his cultural snobbery will prevent him (as opposed to the unassuming consumer of American movies) from entering the kingdom of heaven. The reference to cinema serves in this poem as an indication that the time

33 Vladislav Khodasevich, Stikhotvoreniia (St Petersburg: Akademicheskii proekt, 2001), p. 150. 
of 'sacred' creativity and high spirituality is gone, and the poet-prophet has lost his place in a world of kitsch and crude entertainment.

However, not all poets in Russian Paris were as entrenched in classical national axiologies. Odoevtseva, one of the most flexible and culturally open-minded authors of the Parisian diaspora, was quite keen to imitate popular Western models in prose (this is particularly evident in her novel Zerkalo (The Mirror, 1939)), but occasionally the cinematographic context is apparent in her verse as well. For example, 'Pod lampoi elektricheskoi' ('Under an Electric Lamp') reconstructs a cinematic melodrama in a poetic medium:

Под, лампой электрической

С улыбкой истерической

В подушку головой.

Подстреленная птица,

Нет, это только снится,

Нет, это скверный сон...

И казино, и Ницца,

И звездный небосклон.

И все ж она гордится

Богатством и собой

И горькою судьбой,

Она такая странная,

Прелестная и пьяная -

И вдребезги стакан.

-Вы из далеких стран?

Вам хочется июбить?

Вам хочется пожить

На маленькой земле

В печали и тепле? ${ }^{34}$

Under an electric lamp

With a hysterical smile

and head in the pillow.

34 Iakor', p. 66. 


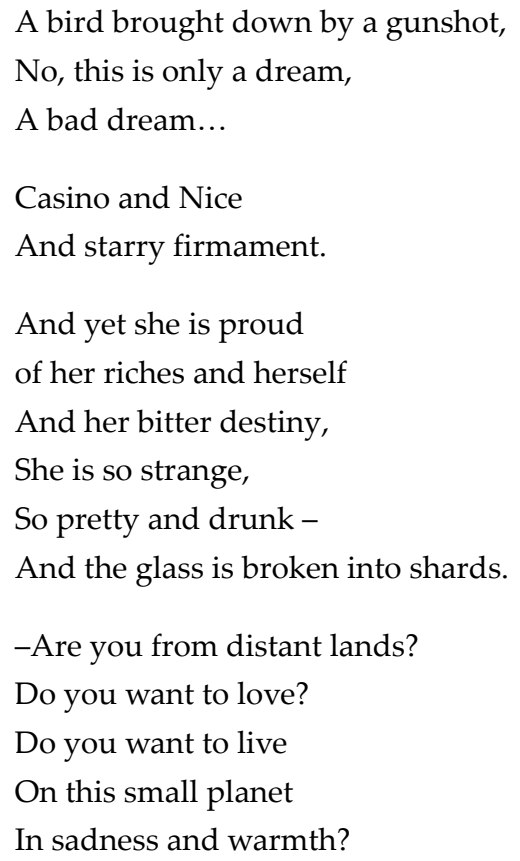

Odoevtseva evokes the hysterical state of the heroine through a rapid succession of images which suggests the accelerated pace of silent movies. Temporal and spatial boundaries are disrupted by elements of montage and juxtaposition as the poet plays with a variety of angles, and combines close-ups with a panoramic view (shifting from the intimate environment of a bedroom to the starry firmament). The boundaries between the real and the imaginary are also blurred by the near-simultaneous depiction of scenes which offer both external and internal perspectives on the heroine's situation (reporting on her behaviour from the outside and then offering insight into her subjective assessment). The poem has an elliptical structure. Not just a graphic glyph, ellipsis was possibly the most common rhetorical figure in Art Deco literature, as it was best suited to convey the sense of acceleration that was pervasive during this era, which was distinguished by the cult of speed. Ellipses also made it possible to cut out all extraneous details and descriptions, inviting the reader to fill in the omitted details, and thereby to move more quickly to the dramatic denouement. Furthermore, Odoevtseva borrows from expressionistic films a melodramatic gesture (the breaking of the glass by the distressed heroine). Concise and evocative, gestures routinely served 
as filters, a way to avoid psychologising or dwelling on feelings. The heightened visual quality and carefully chosen allusions to the most telling markers of modernity (electric light) complete the stage sets.

Odoevtseva's poem is an experiment in adapting Russian verse to the new cultural and material reality, something that many émigré poets, bound by conventional hierarchies, were still reluctant to do. It is nonetheless representative of a certain shift in the cultural discourse of the diaspora: in the 1930s even the established literary 'gurus' began to express the opinion that poetry should more actively respond to the rapidly evolving environment. As Bem stated at a poetic evening in 1933, contemporary émigré poetry 'is forced to reconquer for itself whole new areas of life. Things stamp upon the throat of poetry. [...] It is impossible to protect oneself with the old world of images that have already lost any touch with reality'. ${ }^{35}$

\section{Deracination, Elective Genealogies and Translocal Imagination}

'Pod lampoi elektricheskoi' was included in the only anthology of émigré poetry published during the interwar period, Iakor' (Anchor, 1936). Initiated and edited by Adamovich, the volume included seventyseven poets from diverse regions of the international Russian diaspora, dominated by the Paris Note. In the preface, Adamovich articulates one of the objectives of the collection, which sounds like an expression of the ethos of the Paris Note:

The poet at first blush is talking to himself, often he talks only about himself; the era of oratory has passed and, I would add, to some extent the spiritual energy of this volume is directed precisely at confirming the right to 'agendalessness' and its value, liquidating any belated quixotic pretensions. ${ }^{36}$

The title of the anthology was inspired by Evgenii Baratynskii's poem 'Piroskaf' ('Steamship'), in which the anchor is referred to as a symbol of hope. Baratynskii's image of weighing anchor is recontextualised

35 Al'fred Bem, 'Vstupitel'noe slovo na vechere “Skita” 25 aprelia 1933 g.', Skit. Praga 1922-1940. Antologiia. Biografii. Dokumenty (Moscow: Russkii put', 2006), p. 668.

36 Iakor', p. 6. 
here as a 'navigational'37 or itinerant construction of diasporic identity, emancipated from the place of origin. However, a string of rhetorical questions in the preface suggests a notable vein of self-doubt that Adamovich voices on behalf of the deracinated group, suspended between two worlds, alienated from their homeland and not quite at ease in their adopted country. This sense of vulnerability compels him to resort to the 'letter in a bottle' trope, appealing to the judgment of future generations:

Sometimes we ask ourselves: why didn't we force ourselves to stay there? What is it that we don't accept? In what do we refuse to participate? And what are we doing here anyway? There are many ready-made, reassuring explanations, - but still 'doubt is gnawing at our souls'. The answer is contained in the poems. [...] To express it without pompous phrases - this volume is directed at the future rather than the present, and perhaps the future will find our justification where most of our contemporaries, so eager to discuss various 'missions', saw only lightmindedness, mischief and boredom..$^{38}$

Adamovich's preface reflects internal ambivalence: between the conventional definition of emigration as a 'broken piece' of the homeland ('У нас же не страна, а осколок ее') and the assertion of the autonomy of the new poetic voices that emerge in exile and seek to 'inhabit' immediate reality. ${ }^{39}$ It was crucial for the evolution of the Paris Note, caught between various types of discourse, past and present, Russia and the West, to realise and eventually to break out of this dichotomy. Their sense of belonging to more than one place at a time (inevitably accompanied by a sense of alienation from both places) lends itself to interpretation through the concept of translocality, which designates by a 'place' not only a geographical location but practices, ideas, styles, images, or cultural constructs. Translocal imagination integrates the notions of discontinuity and fluidity that are implicit in the process of migration, with a focus on particular settings, and visualises linkages between them. Ultimately, translocality is a space where diverse

37 Stephen Clingman has argued that the trope of navigation is central to the expression of transnational identities (Stephen Clingman, The Grammar of Identity: Transnational Fiction and the Nature of the Boundary (Oxford: Oxford University Press, 2009), p. 21).

38 Iakor', p. 7.

39 Ibid., p. 6. 
localised narratives establish a dialogic relationship and are thereby transcended, and where hybrid, transnational identities are constituted. For the Paris Note practitioners, the primary locus of these fractured identities was Paris, regarded not only as a cosmopolitan capital and specific place on the map of Western Europe, but above all as an open and dynamic field of inter-cultural exchanges. As Poplavskii summed this up in his article 'Vokrug "Chisel"':

New émigré literature, which has been formed in exile, honestly acknowledges that it does not know anything else and that its best years, the years of the most intense response to the surrounding reality, are spent here, in Paris. Its homeland is neither Russia nor France but Paris. [...] We are the literature of truth about today, which resounds for us like the eternal music of hunger and happiness on Boulevard Montparnasse, as it would have resounded on Kuznetskii Most. [...] We write about our own experience, neither Russian nor French, but Parisian experience. ${ }^{40}$

The translocal imagination of the Paris Note poets shaped their vision of cultural transmission. Under Adamovich's guidance they revised the classical Russian canon, creating for themselves such literary genealogy as would reflect their sensibilities, informed by their experience of modernity as dislocation and cross-cultural alienation. Dismissing Pushkin and the social, religious, philosophical and moral pathos of the nineteenth-century literary mainstream, they turned to Lermontov as the most 'modern' among the Russian classics. Needless to say, using Lermontov as a precursor for the Paris Note was far from straightforward. Glossing over his use of Romantic irony, the émigré poets defined him as a 'tragic', 'lonely', 'misunderstood' and 'rejected' genius. Moreover, the young writers presented him as an archetypal exile and 'cursed poet' ('гонимый миром странник' ('a wanderer chased away by the world')), emphasised the metaphysical content of his texts and pictured him as a forerunner of existentialism. Such reading of Lermontov by émigré poets transformed him from a 'national poet' to 'a diasporic voice in a culture subsisting increasingly on adaptation, hybridity, and live interaction with Western literature, art, and philosophy' ${ }^{41}$

40 Poplavskii, 'Vokrug “Chisel”', in Russkii Parizh (Moscow: MGU, 1998), pp. 288-91 (p. 288).

41 Galin Tihanov, 'Russian Émigré Literary Criticism and Theory between the World Wars', in A History of Russian Literary Theory and Criticism: The Soviet Age and Beyond, edited by Evgenii Dobrenko and Galin Tihanov (Pittsburgh: University of Pittsburgh Press, 2011), pp. 144-62 (p. 162). 
Innokentii Annenskii was another voice claimed by the Paris Note, perhaps with more legitimacy. As Bem points out, Annenskii was appealing to these poets, whose style was distinguished by 'extreme simplicity' of poetic form. ${ }^{42}$ More problematic was their appropriation of Nikolai Gumilev. Given the authority of Adamovich and Ivanov for the Paris Note, the role attributed to Gumilev in the group's self-definition is unsurprising. But in reality, this was a case of false pedigree. Gumilev's flair for exoticism, bright, bold colours, his positive outlook and firm religious beliefs, his preference for epic genres during his later period, and even his occasional mystical and surrealist insights (as in 'Zabludivshiisia tramvai' ('The Tram That Lost Its Way') or 'Ia i vy' ('Me and you')) were a far cry from the colourless, subdued and plaintive tone of the Parisian poets, and of Adamovich himself. The value of craftsmanship, central to the Acmeist conception of poetry, was also dismissed by Adamovich and his disciples, who instead favoured formal imperfection as a path to ultimate sincerity. Paying lip service to Gumilev, Adamovich copied his maittre's organisational, rather than poetic style. ${ }^{43}$

Along with establishing a list of literary models, Adamovich can also be credited with the articulation of canonical principles that would inform the poetics and thematic focus of the Paris Note. The group's texts generally resonated with the 'human document' style of contemporary European writing. ${ }^{44}$ Marked by subjectivity, intimacy, and immediacy, this diary-style poetry was conceived as a private affair, i.e. ostensibly written for oneself, as a means of self-expression and engaging only with the personal world of the lyrical persona, as illustrated by the title of Knorring's collection, Stikhi o sebe (Poems About Myself, 1931). The prevailing tone of confession defined a particular vocabulary, with extensive use of such key words as 'sincerity', 'truth', etc. Lexical poverty and the absence of elaborate rhyme patterns or metaphors corresponded to the existentialist agenda of conveying only the most essential human experience, while also promoting the negative value of personal failure

42 Al'fred Bem, 'Russkaia literatura v emigratsii', in Pis'ma o literature, edited by M. Bubenikova and L. Vakhalovskaia (Prague: Euroslavia, 1996), p. 336.

43 In 1923 Adamovich founded a Guild of Poets in Paris, and mentored his young disciples through regular discussion meetings dedicated to the rigorous analysis of their texts.

44 Obviously, the anti-novelistic and anti-fictional trend was most relevant for émigré prose. But even poetry, especially in the case of the Paris Note, was affected by this radical shift towards a new understanding of literature as testimony and ego-document. 
and creative impotence, a loss of faith in the power of the word, and the poet's anxiety over his inability to express himself adequately. The overuse of dashes, parentheses, elliptical sequences and unfinished sentences suggested disrupted communication, attempts to redefine a feeling or thought ever more accurately, and permanent incompletion. The disjointed, fragmentary nature of the poetic text found organic expression in the genre of lyrical fragment, with its conflation of the 'singular' and the 'universal' and allusions to multiple contexts. ${ }^{45}$ The archetypal emotion of the Paris Note was pity for the 'helpless tongue' and the dream of writing 'without colours and almost without words', as Adamovich declares in the poem 'Stikham svoim ia znaiu tsenu' ('I know the price of my poems'):

Стихам своим я знаю цену.

Мне жаль их, только и всего.

Но ощущаю как измену

Иных поэзий торжество.

Сквозь отступленья, повторенья,

Без красок и почти без слов,

Одно, единое виденье,

Как месяц из-за облаков,

То промелькнет, то исчезает,

То затуманится слегка,

И тихим светом озаряет,

И непреложно примиряет

С беспомощностью языка. ${ }^{46}$

I know the price of my poems.

I'm sorry for them, that's all.

But the glory of the verse of others

I experience as betrayal.

Through digressions, repetitions,

Without colours and almost without words,

45 See I. A. Tarasova, 'Zhanr fragmenta v poezii "Parizhskoi noty"', Zhanry rechi, 1: 11 (2015), pp. 111-16.

46 Georgii Adamovich, 'Stikham svoim ia znaiu tsenu', in Poety parizhskoi noty: $v$ Rossiiu vetrom strochki zaneset, compiled by Vadim Kreid (Moscow: Molodaia gvardiia, 2003), p. 51. 
One single vision,

Like the moon through the clouds.

Now it shows, now it's gone,

Now it fogs up slightly

And sheds quiet light

And brings inevitable reconciliation

With the tongue's helplessness.

With regard to this self-effacing stance of the lyrical voice, Lev Gomolitskii remarked: 'The Parisian poet's ideal would have been achieved if poetry could do completely without words' ${ }^{47}$ An alternative way of obliterating the conventional markers of poetry was 'prosaisation', an aspiration captured by the following lines from Shteiger: 'Who has risked to call himself a poet / Must speak seriously in prose here' ('Тут должен прозой говорить всерьез / Тот, кто рискнул назвать себя поэтом'). ${ }^{48}$

In another iconic poem, Adamovich expressed the sense of entropy engulfing not only poetry but the entire diaspora, depleted of energy and doomed quietly to expire in the midst of Paris. But here, this total despair is welcomed by the lyric persona as a precondition for inspiration and spiritual ascent:

За все, за все спасибо. За войну,

За реводюцию и за изгнанье.

За равнодушно-светлую страну,

Где мы теперь «влачим существованье».

Нет доли сладостней - все потерять.

Нет радостней судьбы - скитальцем стать,

И никогда ты к небу не был ближе,

Чем здесь, устав скучать,

Устав дышать,

Без сил, без денег,

Без любви,

В Париже...49

47 Lev Gomolitskii, 'Nadezhdy simvol', in Iakor', pp. 223-27, p. 224.

48 Anatolii Shteiger, 'Ne do stikhov... Zdes' slishkom mnogo slez', http://gostinaya. net/?p=8387

49 Adamovich, 'Za vse, za vse spasibo. Za voinu', in Poety parizhskoi noty, p. 66. This poem contains transparent intertextual allusions to Georgii Ivanov's nihilist text 
Thank you for everything. For the war,

For the revolution and exile.

For the indifferent bright country

Where we now 'drag out our existence'.

There is no sweeter destiny than to lose everything.

There is no happier fate than to become a vagabond.

And you've never been closer to heaven

Than here, tired of boredom

Tired of breathing,

Without strength, without money,

Without love,

In Paris...

Anatolii Shteiger, who published three books of poetry during his short life, Etot den' (This Day, 1928), Eta Zhizn' (This Life, 1932), and Neblagodarnost' (Ingratitude, 1936), was the most devoted adept of the Paris Note, and arguably he expressed the ethos of the group even more faithfully than Adamovich himself. ${ }^{50}$ Choosing several lines from the second poem of Annenskii's dyptich 'Iiul'" ('July', 1900) ('Подумай, на руках у матерей / Все это были розовые дети' ('Just think, in mothers' arms / They were all pink babies')) as an epigraph to one of his short texts, he explicitly confirmed his poetic genealogy:

Никто, как в детстве, нас не ждет внизу.

Не переводит нас через дорогу.

Про злого муравья и стрекозу

Не говорит. Не учит верить Богу.

'Khorosho, chto net tsaria' ('It is good that there is no czar'), rejected for publication in the leading émigré journal Sovremennye zapiski where Ivanov was otherwise a regular contributor. Its dark irony was lost on the journal's editor, Mark Vishniak, who considered the poem too subversive. As Ivanov recalled in a letter to Roman Gul' of February 14, 1957: 'By the way the only poem that the esteemed Vishniak returned to me back then was "It's good that there is no czar." - "We are against monarchy, but we can't publish such provocation" - these are his genuine words!' (Georgii Ivanov, Irina Odoevtseva, Roman Gul': troistvennyi soiuz (Perepiska 19531958), edited by A. Ar'ev and S. Guan'elli (St Petersburg: Petropolis, 2010), p. 436).

50 See Vadim Kreid, 'V liniiakh notnoi stranitsy...', in Poety parizhskoi noty, pp. 5-30, 12. 
До нас теперь нет дела никому У всех довольно собственного дела. И надо жить, как все, но самому... (Беспомощно, нечестно, неумело). ${ }^{51}$

Nobody waits at the foot of the stairs any more Or takes our hand crossing a street, the way they did When we were young. Nobody tells us about the mean Ant and the Grasshopper. Or teaches us to believe in God.

Nowadays nobody thinks of us at all -

They all have enough just thinking of themselves, So we have to live as they do - but alone...

(Impotent, dishonest, and inept.) ${ }^{52}$

In fact, the two lines in Annenskii's poem immediately preceding those quoted in the epigraph would have defined Shteiger's mood even more precisely: 'Doesn't one get scared sometimes in this world? / Doesn't one want to run and quickly find shelter?' ('Не страшно иь иногда становится на свете? / Не хочется иь бежать, укрыться поскорей?') Annenskii's metaphysical horror before the ugliness, degradation, and brutality to which uncontrollable 'wild forces' subject human beings in the course of their lives is reduced in Shteiger to recurring motifs of fear of life, suffering, lack of vitality, and illness:

Брат мой, друг мой, не бойся страданья,

Как боялся всю жизнь его я... 53

My brother, my friend, don't be afraid of suffering, As I feared it all my life...

51 Anatolii Shteiger, 'Iul', Poety parizhskoi noty, p. 131.

52 Idem, 'Nobody waits at the foot of the stairs any more', translated by Paul Schmidt, in The Bitter Air of Exile, p. 338.

53 Shteiger, 'Esli dni moi milost'iu Boga', in Poety parizhskoi noty, p. 130. 
Этот к вечеру легкий жар,

Кашель ровный и суховатый[...]

Сырость. Сумрак. Последний тлен

И последняя в сердце жалость...

-Трудно книгу поднять с колен,

Чтобы уйти, такова усталость... 54

This light fever towards the evening,

Even and dry cough [...]

Humidity. Twilight. The last decay

And the last pity in the heart...

-It's hard to lift the book from the knees

In order to leave, so strong is the fatigue...

The hospital is a pervasive topos in his verse, which can be defined as 'consumptive' poetry (Shteiger did in fact suffer from tuberculosis, and was treated in a sanatorium for many years before finally succumbing to the disease in Bern during World War Two). It is therefore rather difficult to agree with Struve, who perceived in Shteiger's poetry 'great avidity toward life' ('большая жадность к жизни'). ${ }^{55}$ Rather, it would be fair to suggest that Shteiger's mood correlates with Semen Nadson's plaintive and sorrowful line in Russian poetry, labelled nadsonovshchina (Nadsonovism) by nineteenth-century readers and critics. There are striking parallels between the two poets, even on a biographical level: Nadson also suffered from consumption, was treated in Nice and Bern, and died young. Nadson's confessional intonation, motifs of suffering, ennui, and lament, and even his typical vocabulary (e.g. doubt, ennui, darkness, heavy, futile, difficult, fatal, cruel, insane, beyond one's strength, severe (сомнение, тоска, мгла, тяжкая, напрасная, трудная, роковая, жестокая, безумная, непосильная, суровая)) are echoed in Shteiger's own work and in Paris Note poetry more generally. But as often was the case with the

54 Idem, 'Sentiabr", in ibid., p. 133.

55 Struve, Russkaia literatura v izgnanii, p. 334. 
output of the Paris Note practitioners, plausible Russian pedigree is conflated with references to the cultural realities of contemporary Europe. Literalising the metaphor, Shteiger's motif of physical sickness makes manifest the condition of spiritual and philosophical malaise of the 'European Hamlets', as the post-World War One generation came to be identified in Paul Valéry's 'The Crisis of the Mind' (1919). ${ }^{56}$ Adamovich coined an analogous phrase 'Eastern Hamlets' for young émigré men in his poem 'Kogda my v Rossiiu vernemsia... o, Gamlet vostochnyi, kogda?' ('When Will We Return to Russia... oh, Eastern Hamlet, When?', 1936), intertwining the topos of the hospital, dying and pre-mortem hallucinations with the doom of exile and the unrealisable dream of return. In this way, Adamovich created a more obvious parallel between malady and the émigré condition, whereas in Shteiger it figures as part of his generational experience and perhaps of the human lot more generally.

Shteiger's lyrical persona emerges as a helpless and sick child - frightened, hurt and lonely, quietly lamenting his fate and crying into his pillow at night (the word offence (обида) is recurrent, as well as pain, impotence, boredom, helplessly, tears, children, childish, fear, more frightening (боль, бессилье, скука, беспомощно, слезы, дети, детский, страх, страшнее).

Есть что-то детское и птичье

В словах, делах и снах туберкулезных. ${ }^{57}$

There is something childish and bird-like

In tuberculosis words, acts and dreams.

56 Marcel Arland reintroduced the concept of the 'new malady of the century' in relation to the post-World War One generation in his article 'Sur un nouveau mal du siècle', Nouvelle revue française, 125 (February 1924). On the 'Russification' of this concept and Russian émigrés' fashioning themselves as 'émigré Hamlets' see Leonid Livak, How It Was Done in Paris: Russian Émigré Literature and French Modernism (Madison: Wisconsin University Press, 2003), pp. 26-41.

57 Shteiger, 'Uzhe ne strakh, skoree bezrazlich'e', in Poety parizhskoi noty, p. 140. 


\section{Скоро и глупый плач}

Ночью (во сне) пройдет. ${ }^{58}$

Soon silly crying

At night (in sleep) will also pass.

Но детский страх и наши боль и страх

Одно и то же, в сущности, конечно. ${ }^{59}$

But childish fear and our pain and fear

Are in essence one and the same, of course.

The motifs of infantilism, tears, and futile attempts to revert to the puerile condition were also apparent in Boris Bozhnev's early verse, which in certain respects anticipates the Paris Note:

Чтоб стать ребенком, встану в темный угол,

К сырой стене заплаканным лицом,

И буду думать с гневом и испугом -

За что наказан я, и чьим отцом... ${ }^{60}$

In order to become a child, I will stand in a dark corner,

My tear-stained face toward the moist wall,

And will think with rage and fear -

Why am I punished and by whose father...

Like a meek child, the lyric voice frequently encountered in the poetry of the Paris Note is ready to surrender in the face of misfortune, incapable of resistance. For Shteiger, love is always unhappy, and he unfailingly assumes a passive, effeminate position. Always expecting to be abandoned, his persona lacks even the energy for jealousy ('We even

58 Idem, 'Vremia iskusnyi vrach', in ibid., p. 153.

59 Idem, 'Net v etoi zhizni tiagostnei minut', in ibid., p. 155.

60 Boris Bozhnev, Bor'ba za nesushchestvovan'e (St Petersburg: INAPRESS, 1999), p. 73. 
forgot how to be jealous' ('Мы отучились даже ревновать')) ${ }^{61}$ His only aspiration is to fall into bed and to escape into oblivion:

Отдыхает во сне человек. ${ }^{62}$

Man rests as he sleeps

Неужели опять, чуть стемнело, ничком на кровать -

Чтобы больше не думать, не слышать

И вдруг не заплакать. ${ }^{63}$

Shall I again, as soon as it starts getting dark

Fall face down on the bed -

So as no longer to think or hear

And not to burst out crying suddenly.

When sleep no longer soothes his suffering, the lyric hero entertains suicidal thoughts:

А если уж правда невмочь -

Есть мутная Сена и ночь. ${ }^{64}$

When you can bear it no longer -

There is the muddy Seine and the night.

There is hardly anything mature or 'masculine' in this verse, and Struve's comparison of Shteiger to Anna Akhmatova is partially justified. ${ }^{65}$ Their styles are indeed distinguished by density, clarity, terseness, and abrupt endings. But the heroine of Akhmatova's earlier period at times exudes more vitality, and fashions herself as a femme fatale who makes

61 Shteiger, 'My otuchilis' dazhe revnovat", in Poety parizhskoi noty, p. 144.

62 Idem, 'Otchego, kak stikhaet rech", in ibid., p. 110.

63 Idem, 'Neuzheli sentiabr", in ibid., p. 151.

64 Idem, 'Kryl'ia? Oblomany kryl'ia?', in ibid., p. 116.

65 Struve, Russkaia literatura v izgnanii, p. 334. 
her admirers suffer. By contrast, Shteiger's persona is always on the receiving end:

Где-то теперь мой друг?

Как-то ему живется?

Сердце, не верь, что вдруг

В двери раздастся стук:

Он никогда не вернется. ${ }^{66}$

Where is he now, I wonder?

And what's his life like?

Don't let me sit by the door

Expecting a sudden knock:

He will never come back. ${ }^{67}$

Как нам от громких отучиться слов:

Что значит «самолюбье», «униженье»

(Когда прекрасно знаешь, что готов

На первый знак ответить, первый зов,

На первое малейшее движенье). ${ }^{68}$

How do we break the habit of big words:

What does 'pride' mean? What's 'humiliation'?

(When you know perfectly well I'm ready

to respond to the first sign, the first call,

the first slight gesture.)...69

Shteiger generously plies elliptical closures. Unfinished lines iconically represent his persona's inability to complete any action, his permanent failure in life, hesitation, fatigue and lack of self-confidence. Ellipses also

66 Shteiger, 'Gde-to teper' moi drug?', in Anatolii Shteiger, Dvazhdy dva chetyre: stikhi 1926-1939 (Paris: Rifma, 1950), p. 16.

67 Idem, 'Friendship', translated by Paul Schmidt, in The Bitter Air of Exile, p. 337.

68 Idem, 'Kak nam ot gromkikh otuchit'sia slov', in Poety parizhskoi noty, p. 158.

69 Shteiger, 'How do we break the habit of big words', translated by Paul Schmidt, in The Bitter Air of Exile, p. 337. 
appeal to some common experience that the reader may share, indicate a potential plurality of interpretation, or symbolise the death of poetry and its return to silence:

Мы несчастны. Очень. Боже, Боже,

Отчего Ты с нами не добрей...70

We are unhappy. Very. God, God,

Why aren't You kinder to us...

Только память с нами остается,

Точно крест на брошенной могиле,

И тоска о том, что не вернется,

Что из рук мы сами упустили....71

Only memory stays with us,

Like a cross over an abandoned grave,

And yearning for what will not come back,

For what we let escape from our hands...

Parentheses, another prominent graphic device of the Paris Note, are used by Shteiger to define each emotion in the most precise way, to convey the 'ultimate' truth, to attain complete sincerity. This goal can be achieved only through careful selection of the simplest words and by suppressing all pathos:

Слова печальны и просты,

Не хочет сердце слов заумных. ${ }^{72}$

Words are sad and simple,

The heart wants no highbrow words.

70 Idem, 'Ty osudish'. My ne vinovaty', in Poety parizhskoi noty, p. 134.

71 Idem, 'Vstrecha', in ibid., p. 109.

72 Shteiger, 'Prostoi peizazh', in ibid., p. 118. 
Можно о многом сказать односложно. ${ }^{73}$

Most things can be said in monosyllables.

Along with Shteiger, Akhmatova's émigré double was often identified in the likeness of the beautiful Lydiia Chervinskaia, whose verse was distinguished by 'chamber' tonality, psychological precision, brevity and evocative detail. A friend of Poplavskii, Chervinskaia was also notorious for recreational drug use. Before World War Two, she published two books of poetry, Priblizheniia (Approaches, 1934) and Rassvety (Sunrises, 1937), and contributed verse to a range of émigré journals. A distinctive feature of her style is the extensive use of compound adjectives and rhetorical questions. The Parisian chronotope is easily perceptible in her verse, and the city is represented through restrained but telling details serving as necessary backdrop for the existential drama of Chervinskaia's heroine:

С тобой и с ним, с дождями, с тишиной,

С Парижем в марте, с комнатой ночной,

С мучительно-знакомыми словами,

Неровными, несчитаными днями,

Почти вся мододость...74

With you and him, with rain, with silence,

With Paris in March, with a nocturnal room,

With painfully familiar words,

Uneven, uncounted days,

Almost all my youth...

Город. Огни. Туман.

Все-таки мы умрем.

В комнате темный диван,

Дучше побудем вдвоем. ${ }^{75}$

73 Idem, 'Bessarabiia', in ibid., p. 171.

74 Lydiia Chervinskaia, 'S toboi i s nim', in Poety parizhskoi noty, p. 177.

75 Idem, 'Gorod. Ogni. Tuman', in ibid., p. 183. 
City. Lights. Fog.

But we'll die anyway.

A dark sofa in the room,

Let's better be here together.

In addition to ennui, metaphysical solitude, and unhappy love, her topic of choice is death and failure, and her weak poetic voice tends to fade into whispers and silence:

Вспомнилось... нет, помодчим, подождем.

A recollection... no, let's be silent, let's wait.

Жизнь пройдет и тихо оборвется

В море, в неудачу, в ничего... ${ }^{76}$

Life will pass and quietly drop off

Into the sea, into misfortune, into nothing...

The most characteristic poems of the Paris Note suppress any kind of (auto)biographical information, focusing on pure feeling, emotion, or state of mind in the almost complete absence of specifying context. As in some of Chervinskaia's texts cited above, the lyric voice often simply mentions a place, condition, mood, or the process of recollection, which anyone can access as part of the general human experience. Despite its universal dimension, this conception of poetry arose in the specific environment of the interwar Russian diaspora in Europe.

\section{Conclusion}

The Paris Note corpus embodied the existentialist poetics of the time in its most distilled form. Reflecting the experience of modernity as deracination, marginalisation, and skepticism about any positive teleology, these poets' work was predicated on a mechanism of selfdestruction, as it not only systematically suppressed the classical master

76 Chervinskaia, 'Zhizn' proidet i tikho oborvetsia', ibid., p. 185. 
narrative of Russian literature, with its ideal of the poet as a sage, moral guide and spiritual authority, and the émigré rhetoric of national revival and cultural continuity, but sought to cancel out conventional poetic tropes and even the verbal medium itself. As Igor Chinnov, who identified himself as a 'hanger-on' of the Paris Note, later explained:

Its [Paris Note's - M.R.] hallmark was simplicity - a limited vocabulary, pared down to only the most essential words. We were so eager to replace the specific with the generalized that sea gulls, larks, and nightingales were all reduced to 'birds', while birches, oaks, and weeping willows became 'trees'. We believed that we should write as if there would be no more poetry after us, that what we would write in exile would be the last Russian poetry, and that we should add no ornamentation, nothing superfluous. ${ }^{77}$

The focus of the Paris Note on the entropy of culture and language was an implicit reaction to a variety of socio-historical phenomena and artistic trends, including exile, the instability of publishing networks in the diaspora, the avant-garde, the supremacy of mass culture, ideological crises, and the existentialist discourse of the interwar decades. Their poetry represented a transition between the Silver Age, i.e. fin-desiècle modernism in its Russian incarnation, and interwar modernism, which informed the artistic vocabulary of most Western artists of their generation. In the words of Modris Eksteins, 'Modernism, which in its prewar form was a culture of hope, a vision of synthesis, would turn to a culture of nightmare and denial ${ }^{78}$ Even if, when applied to prewar Russian modernism, its definition as the 'culture of hope' appears reductive, Silver Age poetry conveys the ecstatic expectation of an impending universal transformation, and its eschatological element is inseparable from the intense quest for mystical revelations. After the Revolution, metropolitan Russian literature gradually deviated from European aesthetic trends, and as a result the second phase of modernism was curtailed in the Soviet Union. But this 'culture of nightmare and denial' affected the output of diaspora poets, the Paris Note in the first

77 Conversations in Exile: Russian Writers Abroad, edited by John Glad (Durham, NC, and London: Duke University Press, 1993), p. 33.

78 Modris Eksteins, The Rites of Spring: The Great War and the Birth of the Modern Age (New York: Anchor Books Doubleday, 1990), p. 237. 
instance. ${ }^{79}$ Against the backdrop of metropolitan Russian poetry, the Paris Note strikes a unique chord. Granted, poetry conceived within Soviet borders was extremely diverse, expressing pro-Soviet or dissident sentiments, heroic opposition to tyranny, as well as loneliness and the fear of an oppressive regime, suffering induced by isolation from European civilisation and yearning for a reconnection to world culture, etc. But Paris Note verse is testimony to the profound loneliness and despair of an individual who is located in the epicentre of this 'world culture' and understands that the previously nourishing European civilisation has become a cultural 'wasteland'. The realisation of the emptiness of all conventional notions and words, and of the senselessness of life itself, accounts for the profound introspection of Paris Note poetry as a way to experience this global catastrophe on personal level while 'struggling for non-existence' (in Bozhnev's words). Akhmatova's Rekviem could not have appeared in emigration, just as the meaninglessness of freedom, permeating many lines of the Paris Note, cannot be appreciated by someone who suffers from totalitarian oppression.

Compared to literary developments in the Soviet Union, Paris Note poems embody a different chronotope, expressing cultural and philosophical currents that shaped European modernist culture of the interwar period and in particular the Russian diasporic experience. But some of these texts also transcend their time, place, and individual circumstances, opening themselves to diverse critical readings that can potentially expand their semantics. Without such intense interpretive work, as Mikhail Yampolsky observes, a text cannot attain canonical status. ${ }^{80}$ At the time of publication, Paris Note poems were accompanied by reviews, articles and polemics. ${ }^{81}$ Critics of later periods have likewise

79 Among other prominent examples of diasporic poetic production that expressed this Zeitgeist is Khodasevich's cycle 'Evropeiskaia noch", distinguished by a jarring discontinuity between the 'classical' form cultivated by the poet against all odds and the profoundly modern expression of the collapse of civilisation.

80 Mikhail Iampolskii, 'Literaturnyi kanon i teoriia "sil'nogo avtora"', Inostrannaia literatura, 12 (1998), magazines.russ.ru/inostran/1998/12/iamp.html

81 In post-Soviet Russia, however, the Paris Note has so far enjoyed limited interest beyond the circle of scholars of émigré literature. There have been occasional publications of the Paris Note poems in various collections of émigré lyrics, and at least one book has been released for individual poets, including Shteiger, Chervinskaia, and Chinnov. The Paris Note certainly has not entered the school curriculum, although it is usually introduced as part of university courses on émigré literature. 
agreed that Parisian poets were not epigones of the classical tradition, but trend-setters. Kreid even extended the chronological parameters of the movement far beyond the interwar decades, arguing for its viable and lasting influence:

The idea that the 'Note' existed only in the thirties is false. It was not short-lived, it lasted with diverse modulations for almost half a century - from the 1920s to the 1970s, but most fruitful were the pre-war and postwar decades. 'Note' did not repeat itself, it varied and sounded in various arrangements. ${ }^{82}$

The diasporic canon, inaugurated by the Paris Note along with other émigré authors of the interwar period, opens up new areas of twentieth-century Russian experience, as explored in literary texts. It fosters different approaches to Russian literary identities that cannot be adequately captured from a strictly nationalist perspective on writing, authorship, language, and the poet's status and mission. While it appears to play a provocative role, undermining the fundamental narratives and tropes associated with the mainstream cultural conception of Russianness, it also works against the 'cultural inertia' of the national canon, suggesting an alternative and implicitly contributing to its reconfiguration. ${ }^{83}$

82 Kreid, 'Chto takoe "Parizhskaia nota"', http://magazines.russ.ru/slovo/2004/43/ kr41.html

83 Igor' Sukhikh observes that any established national canon is characterised by 'powerful cultural inertia' (Igor' Sukhikh, Russkii kanon: Knigi XX veka (Moscow: Vremia, 2013)). Although Sukhikh deliberately stays away from poetry in this book, it is nonetheless noteworthy that on his list of thirty canonical figures of twentiethcentury Russian literature he includes several émigrés (among those, the selected texts of Gazdanov and Nabokov clearly belong to the Russian diasporic canon). This demonstrates that canonical boundaries are sufficiently porous for a text to fall within more than one canon, and for diasporic works to be admitted also into a unified, and more comprehensive, canon of Russian literature. 